Kinestetik : Jurnal Ilmiah Pendidikan Jasmani 5 (4) (2021)

Kinestetik : Jurnal Ilmiah Pendidikan Jasmani

https://ejournal.unib.ac.id/index.php/kinestetik/index

DOI : 10.33369/jk.v5i4.19580

\title{
THE POTENTIAL OF WATER-BASED SPORTS IN CULTURAL VIEWING
}

\author{
Herita Warni ${ }^{1 *}$, Syamsul Arifin ${ }^{2}$ Maruful Kahri ${ }^{3} \operatorname{Ramadhan}_{\text {Arifin }}{ }^{4}$
}

${ }^{1234}$ Physical Education, Universitas Lambung Mangkurat

\section{Article Info}

Article History :

Received : December 2021

Revised : December 2021

Accepted : December 2021

Available online : December 2021

Keywords:

Potential, Aquatic Sports, Athlete, Culture

\begin{abstract}
To some extent, the development of sport is influenced by the process of cultural formation. For this reason, it is necessary to explore the potential of culture-based sports by sports experts by paying attention to cultural aspects that allow their potential to be explored and in the end it is expected to produce reliable athletes. However, until now there is almost no research that specifically explores the potential of this culture-based sport. Therefore, this study aims to map the potential of sports that allow for breeding and coaching. This research was conducted through a qualitative approach, with the Naturalistic Inquiry paradigm. Data was collected through interviews, observations and document studies. Source of data for sports management, athletes and documents. The results showed: that 1). Water sports such as diving, rowing, and diving, especially in pool numbers, have the potential to be developed. 2). To be able to develop water sports properly, it is necessary to breed prospective athletes by taking into account the cultural background. 3) The need for continuous management and coaching. The research data is used as study material for local governments and stakeholders in the field of sports to be able to explore the potential of sports that allow them to achieve achievements both at the national and international levels.
\end{abstract}

Corresponding address : Jl. Brigjen Jl. Brigjend Hasan Basri,

Pangeran, Kec. Banjarmasin Utara, Kota Banjarmasin, Kalimantan

Selatan

*Corresponding email : hwarni@ulm.ac.id
ISSN 2685-6514 (Online)

ISSN 2477-331X (Print) 


\section{INTRODUCTION}

Human growth and development is influenced by social society and the environment. On an ongoing basis, humans live always interact between individuals with one another, thus forming interpersonal behavior in the social context and society.

The Indonesian nation is a pluralistic nation, consisting of various ethnic groups. Within the diversity of ethnic groups, there are various local wisdoms, local geniuses or what is also called cultural identity which can also be referred to as the cultural identity or personality of a nation. Local wisdom possessed by the nation is the noble values of the nation's personality giving a message that the Indonesian nation has an identity.

Sports behavior cannot be separated from the characteristics of the place where the perpetrator was born, raised, and spent most of his life. Therefore, it is understandable, if sports achievement is closely related to the socio-cultural characteristics in which a person lives and grows up.

To some extent, the development of sport is influenced by the process of cultural formation. The influencing factors include geography and intercultural contact. (Warni \& Arifin, 2018). The influence of geographical factors on sports can be seen from several countries such as the emergence of longdistance runner athletes from Kenya and Ethiopia, two neighboring countries on the African continent. Likewise, in the short distance events dominated by athletes from Jamaica, the names of Usain Bolt, the men's hundred-meter runner, Thomson Herah, the women's runner, were recorded. Then, in countries with cold climates, many know the sport of ice skiing and ice hockey. Likewise in Indonesia, the development of sports is also inseparable from cultural backgrounds, for example many boxers were born from Maluku, rowers from Southeast Sulawesi and Central Kalimantan, beautiful jumpers, and wrestlers from South Kalimantan. These athletes excel because they are more supported by a specific culture and natural environment. This can be understood because differences in culture and ethnicity are basically included in the concept of the socio-cultural environment which in turn affects the development of motor skills. (Hermawan \& Rachman, 2018). When viewed from the natural environment of lowland Borneo, which is a tropical forest with thickets surrounded by swamps, it is truly a challenging nature, requiring the ability to compete, courage and great energy to be able to conquer it. This inevitably can generate cultural responses that shape attitudes, character and culture. There is a close relationship between the type of work and geographic conditions with "Games and Culture" theorized by (Warni, 2019).

What is appropriate is physical skill. From several illustrations of the achievements of sports originating from certain areas, it is clear that sports behavior cannot be separated from the characteristics of the place where the actor was born, raised, and spent most of 
his life. Therefore, it is understandable, if sports achievement is closely related to the socio-cultural characteristics in which a person lives and grows up.

A glimpse of events a few years ago, around 1985, the emergence of diving athletes from the background of their daily activities involved playing with water, jumping from the Pekapuran bridge and the Antasari bridge jumping into the water with irregular feet, sometimes even somersaulting. This became the forerunner of beautiful diving athletes from South Kalimantan at that time.

Paying attention to the sports achievement data in South Kalimantan from PON to PON has actually been able to rank in the top 10 several times. It was recorded that the last time it was in the top 10 at the XIV PON which was held in Jakarta in 1996. After the XVI PON, the ranking continued to decline, even in the XVIII PON which was held in Riau in 2012, it ranked 19th. In 2016 the XIX PON in West Java's ranking has improved quite a bit, rising to rank XVI, however, it has not been able to enter the top ten. This situation is of course very concerning. From KONI data for South Kalimantan Province, the sports that contributed to medals from PON to PON were dominated by individual branches, including wrestling, diving, weight lifting, archery, rowing, and several other individual sports. From these data, the sport that has never been absent from donating medals is Wrestling, recorded since the VII PON 1966 in Surabaya is Wrestling, is a branch that contributes medals in addition to archery in traditional numbers, rowing, but recently traditional archery no longer competed, while rowing as a contributor to medals from the VII PON in Surabaya seems to be declining, since the XVI PON in Palembang has never donated a medal again.

In the XIV PON, the beautiful diving sport dominated the medals, namely winning 7 gold medals. Even though the beautiful jump has remained as a medal contributor who has never been absent until PON XIX, but from PON to PON it is decreasing. Likewise with weight lifting / weightlifting and bodybuilding. In the XV PON in East Java after winning 8 gold medals, the XVI PON contributed 6 gold medals, after that it decreased. Several individual sports that donated other medals include; air sports, boxing, gymnastics, pencak silat, athletics, table tennis, karate, swimming, motorcycle racing, tekwondo and shooting. The team sport recorded that base ball won a bronze medal at the XVII PON in East Kalimantan, and basketball also won a bronze medal at the XII PON in Jakarta in 1989, however some players came from outside South Kalimantan. (Data from Koni South Kalimantan Province 2012).

From the explanation, it was noted that aquatic sports such as I diving, Rowing, and Diving were recorded as contributors to medals at the highest sporting event in Indonesia, namely PON. This is actually not quite strange because when viewed from the socio-cultural and demographic perspective, South 
Kalimantan is located in a water area, which of course affects the activities of people's lives and sports are no exception. However, the medal contribution from this water sport is not stable. For this reason, it needs to be studied in depth, both in terms of demographics and from a socio-cultural perspective.

\section{METHODS}

The research method used is qualitative, with a naturalistic inquiry paradigm (Lincoln, Y. S., \& Guba, 1985). In this study, the data collected was in the form of 'soft data', meaning that the data obtained were in the form of a rich description of information and a description of the activities carried out. The research was conducted in AprilNovember 2021 in the Banjrmasin and Batola areas. The data collection techniques are through observation and interviews, as well as document studies.

\section{Participants}

The samples of this study were athletes, coaches and administrators of aquatic sports in South Kalimantan.

\section{Materials and Apparatus}

The instrument used in this study uses report cards and documentation. The questionnaire uses the instrument to be made, while the fitness test data collection uses the report card score instrument for physical education subjects.

\section{Procedures}

The implementation of the research is by interviewing several athletes and coaches as well as aquatic sports administrators in South Kalimantan, while also using documentation studies.

\section{Design or Data Analysis}

In this quantitative research, the data analysis technique used is analysis of research data using qualitative, there are no numbers explained by the researcher.(Sugiyono, 2015).(Thomas, J. R., Nelson, J. K., \& Silverman, 2005).

\section{DISCUSSION}

Interviews conducted with data informants P. 1. Water sports (diving). When the researcher asked about the diving sport nursery, he replied 'actually it has huge potential, but the problem is the nursery. There does not appear to be a well programmed nursery, there are only prospective athletes who happen to want to join the practice. The researcher was then asked whether there were any attempts to recruit prospective athletes from the riverbanks, who used to play jumping from trees and bridges. Informant P1 replied, that "in the past it was done by inviting children to exercise who used to jump from bridges, and it worked. But then it was never done again, and the athlete moved to East Java and West Java. Why did they move, ask the researcher. "they are looking for a better livelihood and better development" replied the informant 1 . If so, does that mean the development is not good? Not good, both in terms of facilities and in terms of management. 
Observing the results of the interview with $\mathrm{P} 1$, it can be concluded that during this time there has been stagnation in coaching, and the athlete recruitment system is not well programmed. The potential of diving athletes is very large if the coaches and coaches want to visit the outskirts, where children still like to play in the water.

Interview with A1. A1 stated that A1 joined because he was invited by the coach. "At first I joined gymnastics, I was used to practicing, but I never won. Incidentally, the gymnastics training area is side by side with the beautiful jumping practice. Because he felt that he was not a champion in gymnastics, he felt disappointed, and coincidentally he was offered to take part in the diving exercise. When the researchers asked what about the current athlete nurseries? Nurseries are not programmed properly, those who come to practice just because they want to come along, maybe at the encouragement of their parents, because usually their parents take them to the place of practice. Is there an effort to breed scientifically, for example by looking at the talent in question, or maybe looking at the natural talent possessed by prospective athletes? Ask the researcher. "It's not there yet, there are only those who want it," answered A1.

Observing the results of the interview with $\mathrm{A} 2$, it can be concluded that the coaching system, especially in terms of athlete recruitment, is not going well. Interview with $\mathrm{P} 2$. What is the potential for diving? Ask the researcher. "Diving has opportunities in pool numbers. Why pool numbers, haven't they been followed by marine finswimming numbers? 'No sea finswimming is an athlete from East Java, not from us, he is a Marine who was recruited to become an athlete in South Kalimantan. To practice no finswimming the sea is difficult, because our sea is far from the shore. Meanwhile, if the pool number is enough to practice in the pool, so it's easier.

Observing the results of the interview with $\mathrm{P} 2$, it can be stated that there is a potential for diving in the pool numbers, while in the marine finswimming number, there are problems with training facilities and infrastructure due to the fact that the coast in South Kalimantan is quite far from the sea. From the observations, it can be observed that water culture is closely related to the community, especially those living on the banks of rivers. You can still see children playing in the water, swimming and even jumping into the river from the side of the bridge. Rowing activities have also become a means of water transportation, where people are very adept at rowing canoes in meeting the needs of people's lives. When the researchers made observations in Marabahan, it appeared that the children did not seem afraid to play in the water, they even seemed to be joking. They toyed with the boat quietly, both individually and together with their friends. Likewise, when researchers observed athletes, both beginners and seniors, they seemed proficient in rowing. When the researchers asked them, why were they interested in rowing? They answered that their lives were on the banks of the river, they used to play with their friends in the water one day, even their school was in the water area (a1, A2, A3). When the researchers asked the Batola athletes whether they were native to the local population? On average they 
answered that on average they were native to the South Kalimantan area, even if their parents were from other areas, they were born in Batola (A2, A4, A5, A6). Likewise, what was stated by the trainer and at the same time as a teacher of Physical Education, Sports and Health in Batola (P3), that the majority of these children are indigenous people whose life is attached to water. The results of the analysis of field data can be stated that children living along the river have a habit of playing with water. This makes it possible to become the forerunner of water sports athletes. This is because to a certain extent, the development of sports is influenced by the process of cultural formation. The influencing factors include geography and intercultural contact. (Warni, H., Arifin, S., \& Arifin, 2021). Besides that, ethnic factors also affect participation in sports, this is related to motor skills (Warni, Herita; Mansur, Hamsi; Arifin, Ramadhan; Abbas, 2020).

Environmental conditions that tend to be flowed by rivers are very possible for the development of water sports based on skills from the local cultural heritage. Habits with water make people familiar with water, and of course get rid of the fear of playing in water. How fast the sports process is largely determined by the habits of playing in the surrounding environment (Akhmad, 2012).

The skills possessed from cultural heritage are very likely to become a physical literacy ability, where physical literacy is able to improve the quality of health and fitness of students and the community (Fatoni, R. A., Suroto, S., \& Indahwati, 2020). Periodic physical literacy in a certain time is also able to increase the achievement of a sport (Nerenberg, K. A., Zarnke, K. B., Leung, A. A., Dasgupta, K., Butalia, S., McBrien, K., ... \& Canada, 2018). Good physical literacy skills for children have been shown to increase basic movement maturity, motivation, and self-confidence, so that children are better able to adapt to movements that have not been mastered (Gustian, U., Supriatna, E., \& Purnomo, 2019). A glimpse of events a few years ago, around 1985, the emergence of diving athletes from the background of their daily activities involved playing with water, jumping from the Pekapuran bridge and the Antasari bridge jumping into the water with irregular feet, sometimes even somersaulting. This became the forerunner of beautiful diving athletes from South Kalimantan at that time.

Humans are a cultural species. (Colagè, I., \& d'Errico, 2020). Human growth and development cannot be separated from the social influence of society and the environment. Culture is the main driving force for humans. (Colagè, I., \& d'Errico, 2020) Society also reflects cultural diversity. Each community group supports and develops culture, and manifests it in various distinctive gang actions that reflect the aspirations of its culture and society.

Human life always interacts continuously and continuously, between individuals with one another, thus forming interpersonal behavior in the social context and society. Cultural evolution based on learning and social experience (De Munck, V. C., \& Bennardo, 2019). Culture is "the total complex of knowledge, belief, art, morals, 
law, customs and all other capabilities and habits acquired by a person as a member of society. (Ade, V., \& Affandi, 2016). This is hereditary and can shift due to interaction.

Each community group uses its culture to provide survival and education in its own way. There are several types of society related to the type of physical activity based on culture. First type. Although not influenced by other cultural diversity, physical activity is always present in it even though the community is isolated. These physical activities can be in the form of increasing physical strength, belief in supernatural powers, ritual ceremonies, filling spare time, fulfilling primary needs such as hunting, fishing, fishing. Basically, this first type develops physical skills as an adaptive strategy to meet physical and social needs in order to sustain life and improve their welfare in their own way. Second type. This society has begun to be contaminated by other cultures as a consequence of inter-ethnic interactions. This society is more open, and accepts culture including physical activity in the form of sports openly, but is still strongly bound to its traditional culture. Third type. The community has long been in contact with various cultures from outside their ethnicity. This society is also called a plural society, the majority of which live in urban areas, so that physical activities such as sports are already in the form of standard modern sports. In a society like this, for sports activities, facilities and infrastructure are needed to support activities. Physical activity in sports is more aimed at achieving measurable achievements

\section{CONCLUSION}

The Children living along river paths have a habit of playing with water and have the potential to become athletes in aquatic sports. Rowing athletes can be recruited through marine culture-based talent scouting. Children who have the courage to jump from a height, such as from a tree plunging into the water or from a bridge plunging into the water, can be used as aunts for diving athletes. The main point here is courage. With the capital of courage, it will be easier to direct these children to become diving athletes. Prospective divers, especially those with no pools, can be recruited through children who have the habit of swimming, especially children who have the courage to swim while diving in rivers.

\section{ACKNOWLEDGEMENT}

We convey our gratitude to the chairman of the Institute for Research and Community Service who has provided assistance so that the implementation of this research can run well.

\section{REFERENCES}

Ade, V., \& Affandi, I. (2016). Implementasi Nilai-Nilai Kearifan Lokal Dalam Mengembangkan Keterampilan Kewarganegaraan (Studi Deskriptif Analitik Pada Masyarakat Talang Mamak Kec. Rakit Kulim, Kab. Indragiri Hulu Provinsi Riau). Jurnal Pendidikan Ilmu Sosial, 25(1), 77-91.

Akhmad, I. (2012). Tinjauan Filosop Tentang Makna Olahraga Dan Prestasi Olahraga. Majalah Keolahragaan Sportif, 6(2), 176-185. 
Colagè, I., \& D'errico, F. (2020). Culture: The Driving Force Of Human Cognition. Topics. In Cognitive Science, 12(2), 654-672.

De Munck, V. C., \& Bennardo, G. (2019). Disciplining Culture: A Sociocognitive Approach. Current Anthropology, 60(2), 174-193.

Fatoni, R. A., Suroto, S., \& Indahwati, N. (2020). Pengaruh Aktivitas Fisik Program Gross Motor Skill Terhadap Indeks Massa Tubuh Dan Tingkat Kebugaran Jasmani. Multilateral: Jurnal Pendidikan Jasmani Dan Olahraga, 20(1), 1-10.

Gustian, U., Supriatna, E., \& Purnomo, E. (2019). Ktifitas Modifikasi Permainan Tradisional Dalam Pengembangan Physical Literacy Anak Taman KanakKanak. Jurnal Keolahragaan, 7(1), 2333.

Hermawan, D. A., \& Rachman, H. A. (2018). Pengaruh Pendekatan Latihan Dan Koordinasi Mata Tangan Terhadap Ketepatan Shooting Peserta Ekstrakurikuler Basket. Jurnal Keolahragaan, 6(2), 100-109. Https://Doi.Org/10.21831/Jk.V0i0.2034 9

Lincoln, Y. S., \& Guba, E. G. (1985). Naturalistic Inquiry. Sage.

Nasution, I. E., \& Suharjana, S. (2015). Pengembangan Model Latihan Sepak Bola Berbasis Kelincahan Dengan Pendekatan Bermain. Jurnal Keolahragaan. Https://Doi.Org/10.21831/Jk.V3i2.6241

Nerenberg, K. A., Zarnke, K. B., Leung, A. A., Dasgupta, K., Butalia, S., Mcbrien, K. \& Canada, H. (2018). Hypertension Canada's 2018 Guidelines For Diagnosis, Risk Assessment, Prevention, And Treatment Of Hypertension In Adults And Children. Canadian Journal Of Cardiology, 34(5), 506-525.

Sugiyono. (2015). Metode Penelitian \& Pengembangan Research And Development. Bandung: Alfabeta.

Thomas, J. R., Nelson, J. K., \& Silverman, S. J. (2005). Reseach Methods In Physical Activity. United States Of America: Human Kinetics.
Warni, H., Arifin, S., \& Arifin, R. (2021). Karakteristik Pembelajaran Pendidikan Jasmani Olahraga Kesehatan (Pjok) Di Lingkungan Lahan Basah. In Prosiding Seminar Nasional Lingkungan Lahan Basah, 6/1.

Warni, Herita; Mansur, Hamsi; Arifin, Ramadhan; Abbas, E. W. (2020). Between Hope And Reality: Curriculum 13 (K-13) Implementation In Teacher's Ability To Develop Learning Devices In The Era 4.0. 35th Ibima Conference.

Warni, H. (2019). Character Transformation Through Sports Achievement: A Naturalistic Study Of Athletes In South Kalimantan. 28(8), 373-382. Http://Sersc.Org/Journals/Index.Php/Ija st/Article/View/566

Warni, H., \& Arifin, R. (2018). Character Building Values In Sports Development (Vol. 1, Issue Icsshpe 2017, Pp. 231234). 